\title{
CONVERGENCE OR DIVERGENCE OF BASIC MACROECONOMIC VARIABLES IN THE DISTRICTS OF PODKARPACKIE PROVINCE
}

\begin{abstract}
The paper presents the results of statistical analyses of $\sigma$ and $\beta$ real convergence processes of selected macroeconomic variables at the level of districts in Podkarpackie Province. The study comprises the data on unemployment rates, real gross wages, business investments per capita and gross industrial production sold per capita in the period 20022011 obtained from the Bank of Local Data in Central Statistical Office. Moreover, the taxonomic indicator of development for Podkarpackie Province was calculated and also subjected to statistical analysis. The main purpose of the study is to verify the hypothesis on the existence of the convergence of the analysed variables and the taxonomic indicator of development, calculated at the level of the districts in Podkarpacie. $\Sigma$-convergence analysis was based on the indicators of the spatial variation of the above mentioned variables, i.e.: maximum, minimum, the ratio of maximum/minimum, the coefficients of variation based on the quartile deviation $\left(\mathrm{V}_{\mathrm{Q}}\right)$, the standard deviation $\left(\mathrm{V}_{\mathrm{S}}\right)$ and the average deviation $\left(\mathrm{V}_{\mathrm{d}}\right)$. Owing to the values of the calculated coefficients of variation there was observed spatial heterogeneity of the analysed variables and the taxonomic indicator of development, whereas their changes over time allowed the identification of the phenomenon of $\sigma$ convergence or $\sigma$-divergence. The analysis of $\beta$ real convergence consisted in the estimation of the parameters of the equation of 'pure convergence' of Barro's type. Furthermore, in order to take into account the spatial heterogeneity of the analysed variables, the real convergence equations were extended by introducing individual fixed effects. The equations proposed in the article were estimated using a panel method by means of the instrumental variables method that is the most appropriate one for this type of equations, namely generalized method of moments.
\end{abstract}

Keywords: convergence, divergence, labor market, taxonomic indicator of development, local unemployment rate, real gross wages, industrial production sold per capita, generalized method of moments (GMM).

\section{INTRODUCTION}

Convergence effect, not only in theoretical considerations but also empirical studies is defined as a process in which different initial values of basic macroeconomic variables at the level of countries, regions and sub-regions become equal ${ }^{2}$. Therefore, this notion refers to the convergence of the ratios typical of economic development, i.e., growth rate and the level of GDP per capita, production sold and investment, however, also other

\footnotetext{
${ }^{1}$ Tomasz Misiak, PhD, Faculty of Economics, Rzeszów University of Technology, al. Powstańców Warszawy 10, 35-959 Rzeszów, tel. (017) 8651403, email: tmisiak@prz.edu.pl.

${ }^{2}$ Cf. Ł. Jabłoński, T. Tokarski, Taksonomiczne wskaźniki przestrzennego zróżnicowania rozwoju powiatów, „Studia Prawno-Ekonomiczne” t. LXXXVIII/2013, p.267.
} 
variables can be analysed, e.g., the ones concerning labour market, such as average real gross wages or unemployment rates.

Owing to the determination of the process of real convergence it is possible to answer the question whether countries, regions or subregions that substantially differ in the initial levels of the analysed variables, widen or narrow the development gap between them. The narrowing of a development gap between, e.g., regions or sub-regions, measured using appropriate macroeconomic indexes, denotes the existence of the process of real convergence. Accordingly, the increase in development variations between countries, regions or subregions signifies the process of real divergence ${ }^{3}$.

Therefore, the main purpose of the present paper is an attempt to statistically analyse the processes of $\sigma$ - and $\beta$-real convergence/divergence of the selected macroeconomic variables at the level of districts in Podkarpackie Province. The analysis was conducted on the basis of the statistical data relating to district registered unemployment rates, real gross wages, business investments per capita and industrial production sold per capita ${ }^{4}$ for 2002-2011, which are available on the official website of Central Statistical Office (CSO) (www.stat.gov.pl). Moreover, on the basis of the analysed variables, there was calculated a taxonomic indicator, which is a geometric mean of two indicators: ED (taxonomic distance indicator in Euclidean space) and RD (taxonomic distance indicator in rectilinear space), which was also analysed in terms of convergence/divergence.

The present paper is divided into a few sections. Section 2 describes theoretical aspects of the processes of $\sigma$ - and $\beta$ - real convergence/divergence of macroeconomic variables. Section 3 comprises the analyses of the intraregional variation of the above mentioned macroeconomic variables in Podkarpackie Province and also the process of $\sigma$ convergence/divergence. In section 4 there are included the estimations of the parameters of convergence/divergence equations for the variables analysed in the paper. This part is followed by a summarising section which also contains conclusions.

\section{METHODS OF CONVERGENCE/DIVERGENCE ANALYSIS}

In the majority of the analyses of the process of $\beta$-convergence, the starting point is the equation of the increase in the labour efficiency ratio that ensues from the model proposed by R.M. Solow [1956], which reads as follows:

$$
\ln \left(y_{i t} / y_{i 0}\right)=\alpha-\left(1-e^{-\beta t}\right) \cdot \ln \left(y_{i 0}\right)+\xi_{i t}
$$

where, $y_{i 0}$ - the level of product per worker (or other macroeconomic variable, e.g., GDP or production sold) in $i$-region, subregion in the initial period; $y_{i t}$ - the level of product per worker in $t$ - period; $\alpha-$ a constant; $\xi_{i t}$ - random component describing random shocks in $i$ region, subregion in $i$-period.

In equation (1), parameter $\beta$ determines the rate of unconditional (absolute) convergence, which informs about the percentage of the distance a country, region or subregion covers towards achieving steady state within one period, e.g., over a year. $\beta$ parameter is calculated by the method of non-linear least squares or estimated by the

\footnotetext{
${ }^{3}$ T. Misiak, A. Sulima, T.Tokarski, Czy w polskich powiatach wystepuje efekt konwergencji realnej? [in:] W. Kwiatkowska, E. Kwiatkowski (ed.) Wzrost gospodarczy $i$ polityka makroekonomiczna, Wydawnictwo Uniwersytetu Łódzkiego, Łódź 2010, p. 198.

${ }^{4}$ Certainly, GDP per capita is a better yardstick for this type of analyses, however CSO does not estimate GDP at the level of districts.
} 
method of least squares (LS). Subsequently, the speed of $\beta$-convergence is calculated using the following equation: $b=\left(1-e^{-\beta t}\right)$. Frequently, due to the shortcomings of the above mentioned estimation methods for panel data, generalized method of moments (hereafter: GMM) is applied.

To fully describe the process of $\beta$-convergence a few equations of convergence describing the relationship between the growth rate of regional GDP per capita in $t$-year and the value of this variable in the previous year $(t-1)$ were used.

Basing on equation (1) the equation of 'pure convergence' can be determined; in the literature it is also called Barro's equation which reads as follows ${ }^{5}$ :

$$
\Delta \ln \left(y_{i t}\right)=\alpha_{0}+\beta \ln \left(y_{i t-1}\right)
$$

where: $y_{i t}-$ the value of, e.g., real production sold per capita in $i$-district (where $i=1,2, \ldots 25)$ in $t$-year or other macroeconomic variable analysed in the paper, $\Delta \ln \left(y_{i t}\right)-$ growth rate of the production sold per capita in $i$-district, $\alpha_{0}-$ a constant with no direct economic interpretation, $\beta$ - parameter explaining the influence of the value of production sold per capita from the previous year on the growth rate of this variable in $t$-year.

Therefore, negative value of $\beta$ parameter estimated in equation (2) signifies the existence of $\beta$-convergence, or else, that the district with lower level of, e.g., production sold per capita develops quicker than the districts with higher production sold per capita, irrespective of the values of the remaining economic quantities. Positive value of $\beta$ parameter implies the existence of $\beta$-divergence. When $\beta$-parameter equals zero, there is no correlation between the growth rate and the initial level of a given macroeconomic variable.

In the case of the analyses of $\beta$-convergence of the registered unemployment rates, the correlation between the changes of the unemployment rate in $t$-year and the unemployment rate in the previous year is described with the following equation of convergence/divergence:

$$
\Delta u_{i t}=\alpha_{0}+\beta u_{i t-1}
$$

where $u_{i t}$ denotes the unemployment rate in $i$-district in $t$-year.

Furthermore, equations ( 2 and 3 ) were extended using the procedure based on fixed effects, i.e., variation of arbitrary constants. The use of this procedure enabled taking into account spatial heterogeneity of the analysed macroeconomic variables, as well as achieving the results which were closer to the estimations of conditional convergence ${ }^{6}$.

Hence, equation (2) was transformed into:

\footnotetext{
${ }^{5}$ See.: inter alia: B. Gramic, Convergence in per-capita GDP across European regions, "Economic and Business Review" 2006, vol. 8, no. 2, pp. 185-208, or M. Sassi, OLS and GWR approaches to agricultural convergence in the EU-15, "International Advances in Economic Research" 2010, vol. 16 , no. 1 .

${ }^{6}$ The procedure of fixed effects was first used in the research on convergence between countries by: N. Islam, What Have We Learnt From the Convergence Debate, „Journal of Economic Surveys” 2003, vol. 17(3), whereas in the research on convergence between regions this method was applied, among others, by: F. Canova, A. Marcet, The poor stay poor: non-convergence across countries and regions, "CEPR Discussion Papers" 1995, no. 1295, V. Meliciani, F. Peracchi, Convergence in per capita GDP across European regions: a reappraisal, "Empirical Economics" 2006, vol. 31, and M. Sassi [2011] Convergence across the EU regions: Economic composition and structural transformation, "International Advances in Economic Research" 2011, vol. 17.
} 


$$
\Delta \ln \left(y_{i t}\right)=\alpha_{0}+\sum_{j=1}^{n} \phi_{j} d_{j}-\beta \ln \left(y_{i t-1}\right)
$$

where: $d_{j}$ - dummy variable for $j$ non-base district.

Equation (3) has the form:

$$
\Delta u_{i t}=\alpha_{0}+\sum_{j=1}^{n} \phi_{j} d_{j}+\beta u_{i t-1}
$$

It is worth emphasising that whereas $\alpha_{0}$ parameter in equations (4 and 5) is a constant only for the base district, the estimated $\square_{j}$ parameters allows the determination of the number of which the growth rate ceteris paribus of the analysed macroeconomic variable in a given district in Podkarpackie Province was higher (lower) than in the base district if it had similar values of macroeconomic variables to those of the base district.

Moreover, on the basis of the above equations one can attempt the determination of long-term theoretical values of the variables being analysed. For this purpose, it has to be assumed that in equation (2) $x_{t}=\ln y_{i t}$, hence the equation has the form:

$$
\forall t \in \mathfrak{W}-\{0\} \quad x_{t}-x_{t-1}=\alpha+\beta x_{t-1}
$$

Equation (6) can be transformed into:

$$
\forall t \in \mathcal{N}-\{0\} \quad x_{t}=\alpha+(1+\beta) x_{t-1}
$$

and if $(1+\beta)$ is replaced with $\gamma$, equation (7) reads as follows:

$$
\forall t \in \mathfrak{\aleph}-\{0\} \quad x_{t}=\alpha+\not x_{t-1}
$$

It ensues from equation (8) that for any $n \in \mathcal{N}$ the correlation between the value of the variable in $n$ period and the initial value of this variable (i.e., in the year $t=0$ ) is described by the relation:

$$
x_{n}=\alpha \sum_{i=0}^{n-1} \gamma^{i}+\gamma^{n} x_{0}
$$

If $\beta \in(-1,0)$, then $\gamma \in(0,1)$, and estimating the limit (where $n \rightarrow+\infty)$ from $x_{n}$ a longperiod theoretical value of explanatory variable is obtained:

$$
x^{*}=\lim _{n \rightarrow \infty} x_{n}=\alpha \frac{1}{1-\gamma}=-\frac{\alpha}{\beta}
$$

where $x^{*}=\ln y^{*}$, thus $y^{*}=e^{-\frac{\alpha}{\beta}}$. Equation

(3), referring to the growth in unemployment rate, can be transformed as follows:

$$
u_{t}-u_{t-1}=\alpha+\beta u_{t-1}
$$


Equation (11) is analogous to equation (6), thus long-period theoretical value of unemployment rate equals $u^{*}=-\frac{\alpha}{\beta}$.

Equations (2-5) were estimated using generalized method of moments (GMM).

The hypothesis on $\sigma$-convergence in the groups of the examined regions was verified using measures of relative variation, i.e., the coefficients of variation based on standard deviation $\left(\mathrm{V}_{\mathrm{S}}\right)$, quartile deviation $\left(\mathrm{V}_{\mathrm{Q}}\right)$ and the average deviation $\left(\mathrm{V}_{\mathrm{d}}\right)^{7}$. Therefore, what ensues from the values of these coefficients declining over time is the existence of $\sigma$ convergence, whereas from the increasing ones - deepening disproportions between regions, i.e., $\sigma$-divergence. It is worth emphasising that to examine longer time series also the $\sigma$-convergence approach is applied, which is based on the equation of $\sigma$-convergence regression ${ }^{8}$. However, owing to a relatively short period of analysis, i.e., 2002-2011 (ten periods), in the examination of $\sigma$-convergence only the coefficients of variation $\left(\mathrm{V}_{\mathrm{S}}, \mathrm{V}_{\mathrm{Q}} \mathrm{i}\right.$ and $\mathrm{V}_{\mathrm{d}}$ ) were applied.

\section{SPATIAL VARIATION OF MACROECONOMIC VARIABLES AT THE LEVEL OF DISTRICTS IN PODKARPACKIE PROVINCE}

Spatial variation of the macroeconomic variables from 2002-2011 analysed in the paper is depicted in table 1 and figure 1 . The following conclusions of economic nature can be drawn from these data and from the analysed statistical data:

- Throughout the entire period of the analysis the highest values of real gross wages were recorded in the capital city of the province (city district of Rzeszów). Average gross wages in this district amounted to about PLN 2500 in 2002 and PLN 3301 in 2011. The level of wages recorded in the capital city of Podkarpacie was almost twice lower than in Lubiński District (Dolnośląskie Province) or Jastrzębie Zdrój (Śląskie Province), in which there was registered the highest level of average real gross wages at the level of Polish districts and amounted to over PLN 6300 in 2011. Interestingly, in 2011 in Warsaw the average real gross wages were about PLN 1300 lower than in the districts Lubiński and Jastrzębie Zdrój.

- The minimum values of average real gross wages were recorded in the districts: Niżański (2002-2005), Strzyżowski (2006-2008), Łańcucki (2009) Krośnieński (2010) and again in Strzyżowski (2011). In 2011 the minimum average real gross wages in Podkarpackie Province was about PLN 900 lower than the average maximum wages.

\footnotetext{
${ }^{7}$ Cf., e.g., J. Jóźwiak, J. Podgórski, Statystyka od podstaw, PWE, Warszawa 2000, pp. 52-53.

${ }^{8}$ Cf. M. Próchniak, R. Rapacki, Konwergencja typu beta $(\beta)$ i sigma $(\sigma) w$ krajach transformacji $w$ latach 1990-2005, [in:] R. Rapacki (ed.), Wzrost gospodarczy $w$ krajach transformacji. Konwergencja czy dywergencja?, PWE, Warszawa 2009, p.147, or K. Malaga Konwergencja gospodarcza w krajach OECD w świetle zagregowanych modeli wzrostu, Prace habilitacyjne, $\mathrm{nr} 10$, Wydawnictwo Akademii Ekonomicznej w Poznaniu, Poznań 2004.
} 
Table 1. The variation of macroeconomic variables in Podkarpackie Province in 2002-2011

\begin{tabular}{|c|c|c|c|c|c|c|c|c|c|c|}
\hline & 2002 & 2003 & 2004 & 2005 & 2006 & 2007 & 2008 & 2009 & 2010 & 2011 \\
\hline \multicolumn{11}{|c|}{ Real gross wages [PLN] } \\
\hline \multirow{2}{*}{$\max$} & 2500 & 2595 & 2614 & 2698 & 2789 & 2949 & 3216 & 3258 & 3341 & 3301 \\
\hline & Rzeszów & Rzeszów & Rzeszów & Rzeszów & Rzeszów & Rzeszów & Rzeszów & Rzeszów & Rzeszów & Rzeszów \\
\hline \multirow{2}{*}{$\min$} & 1919 & 1979 & 2012 & 1998 & 2082 & 2212 & 2334 & 2361 & 2438 & 2446 \\
\hline & Niżański & Niżański & Niżański & Niżański & Strzyżowski & Strzyżowski & Strzyżowski & Łańcucki & Krośnieński & Strzyżowski \\
\hline $\begin{array}{c}\max / \\
\min \end{array}$ & 1,30 & 1,31 & 1,30 & 1,35 & 1,34 & 1,33 & 1,38 & 1,38 & 1,37 & 1,35 \\
\hline \multicolumn{11}{|c|}{ The coefficient of variation } \\
\hline $\mathbf{V}_{\mathbf{Q}}$ & 0,04 & 0,05 & 0,05 & 0,04 & 0,05 & 0,04 & 0,05 & 0,05 & 0,05 & 0,04 \\
\hline $\mathbf{V}_{\mathrm{S}}$ & 0,06 & 0,07 & 0,07 & 0,07 & 0,07 & 0,07 & 0,08 & 08 & 0,07 & 0,07 \\
\hline $\mathbf{V}_{\mathrm{d}}$ & 0,05 & 0,05 & 0,05 & 0,05 & 0,06 & 0,06 & 0,06 & 0,06 & 0,05 & 0,05 \\
\hline \multicolumn{11}{|c|}{ Registered unemployment rate [\%] } \\
\hline \multirow{2}{*}{$\max$} & $27,1 \%$ & $31,9 \%$ & $30,4 \%$ & $29,1 \%$ & $27,1 \%$ & $22,9 \%$ & $25,7 \%$ & $25,7 \%$ & $25,9 \%$ & $24,1 \%$ \\
\hline & Bieszczadzki & Bieszczadzki & Biesczadzki & Bieszczadzk & Bieszczadzki & Leski & Bieszczadzki & Bieszczadzki & Leski & Niżański \\
\hline \multirow[b]{2}{*}{$\min$} & $9,8 \%$ & $9,3 \%$ & $8,1 \%$ & $8,3 \%$ & $6,7 \%$ & $4,8 \%$ & $5,3 \%$ & $7,2 \%$ & $7,6 \%$ & $7,1 \%$ \\
\hline & $\begin{array}{c}\text { Rzeszó } \\
\text { w }\end{array}$ & $\begin{array}{c}\text { Rzeszó } \\
\text { w }\end{array}$ & Krosno & Krosno & Krosno & Krosno & Rzeszów & Rzeszów & Krosno & Krosno \\
\hline $\begin{array}{c}\max / \\
\min \end{array}$ & 2,77 & $\mathbf{3 , 4 3}$ & 3,75 & 3,51 & 4,04 & 4,77 & 4,85 & 3,57 & 3,41 & 3,39 \\
\hline \multicolumn{11}{|c|}{ The coefficient of variation } \\
\hline $\mathbf{V}_{\mathbf{Q}}$ & 0,08 & 0,09 & 0,11 & 0,10 & 0,11 & 0,17 & 0,23 & 0,12 & 0,13 & 0,14 \\
\hline $\mathbf{V}_{\mathrm{S}}$ & 0,19 & 0,24 & 0,24 & 0,24 & 0,27 & 0,29 & 0,2 & 0,27 & 0,28 & 0,26 \\
\hline $\mathbf{V}_{\mathrm{d}}$ & 0,13 & 0,17 & 0,17 & 0,17 & 0,20 & 0,22 & 0,25 & 0,20 & 0,22 & 0,20 \\
\hline \multicolumn{11}{|c|}{ Business investments per capita [thousand PLN] } \\
\hline \multirow{2}{*}{$\max$} & 4,80 & 3,86 & 3,88 & 4,34 & 4,10 & 4,81 & 5,72 & 5,48 & 4,94 & 7,50 \\
\hline & Rzeszów & Rzeszów & Rzeszów & Rzeszów & Rzeszów & Rzeszów & Rzeszów & Rzeszów & Rzeszów & Tarnobrzeski \\
\hline \multirow{2}{*}{$\min$} & 0,14 & 0,20 & 0,24 & 0,27 & 0,21 & 0,31 & 0,23 & 0,19 & 0,32 & 0,45 \\
\hline & Przemyski & Krośnieński & Strzyżowski & Strzyżowski & Strzyżowski & Strzyżowski & Strzyżowski & Strzyżowski & Strzyżowski & Strzyżowski \\
\hline$\underset{\min }{\max }$ & 34,22 & 19,11 & 15,88 & 16,07 & 19,61 & 15,51 & 24,77 & 28,73 & 15,28 & 16,51 \\
\hline \multicolumn{11}{|c|}{ The coefficient of variation } \\
\hline $\mathbf{V}_{Q}$ & 0,59 & 0,37 & 0,38 & 0,33 & 0,50 & 0,50 & 0,40 & 0,41 & 0,42 & 0,76 \\
\hline $\mathbf{V}_{\mathrm{S}}$ & 1,05 & 0,83 & 0,82 & 0,74 & 0,73 & 0,76 & 0,73 & 0,76 & 0,66 & 0,83 \\
\hline $\mathbf{V}_{\mathbf{d}}$ & 0,70 & 0,59 & 0,61 & 0,51 & 0,57 & 0,58 & 0,53 & 0,52 & 0,51 & 0,66 \\
\hline \multicolumn{11}{|c|}{ Industrial production sold per capita [thousand PLN] } \\
\hline \multirow{2}{*}{$\max$} & 23,85 & 27,38 & 33,62 & 30,44 & 35,26 & 39,06 & 34,93 & 32,02 & 34,39 & 36,99 \\
\hline & Mielecki & Mielecki & Mielecki & Mieleck & Mielecki & Mielecki & Mielecki & Mielecki & Stalowowol. & Mielecki \\
\hline \multirow{2}{*}{$\min$} & 1,02 & 1,06 & 0,92 & 0,89 & 0,73 & 0,96 & 0,88 & 0,84 & 0,89 & 0,90 \\
\hline & Przemyski & Przemyski & Przemyski & Przemysk & Przemyski & i|Przemyski & Przemyski & |Przemyski & Przemyski & Przemyski \\
\hline $\begin{array}{c}\max / \\
\min \end{array}$ & 23,35 & 25,84 & 36,50 & 34,03 & 48,62 & 40,56 & 39,84 & 38,07 & 38,66 & 41,20 \\
\hline \multicolumn{11}{|c|}{ The coefficient of variation } \\
\hline $\mathbf{V}_{Q}$ & 0,65 & 0,73 & 0,73 & 0,80 & 0,81 & 0,65 & 0,65 & 0,58 & 0,62 & 0,61 \\
\hline $\mathbf{V}_{\mathbf{S}}$ & 0,83 & 0,84 & 0,85 & 0,84 & 0,85 & 0,87 & 0,83 & 0,81 & 0,83 & 0,79 \\
\hline$\overline{\mathbf{V}_{\mathrm{d}}}$ & 0,68 & 0,70 & 0,69 & 0,70 & 0,69 & 0,69 & 0,67 & 0,65 & 0,65 & 0,63 \\
\hline
\end{tabular}

Source: self-estimations on the basis of CSO's data from www.stat.gov.pl

- While comparing the maximum-minimum wages ratio, one can conclude that the maximum values of this variable were increasing slightly faster than its minimum levels, which ensues from the fact that this coefficient was characterised by a slight growth tendency. Therefore, it can imply that this variable is influenced by real $\sigma$ convergence. Taking into consideration the estimated coefficients of variation for 
real gross wages, it transpires that even though these coefficients in 2011 were at a similar or somewhat higher level than in 2002, this growth was almost imperceptible, as, depending on the method of estimating the coefficient of variation, it amounted to about 0,01 .

Fig. 1. The coefficients of variation $\left(\mathrm{V}_{\mathrm{Q}}\right)$ of the analysed variables in Podkarpackie Province

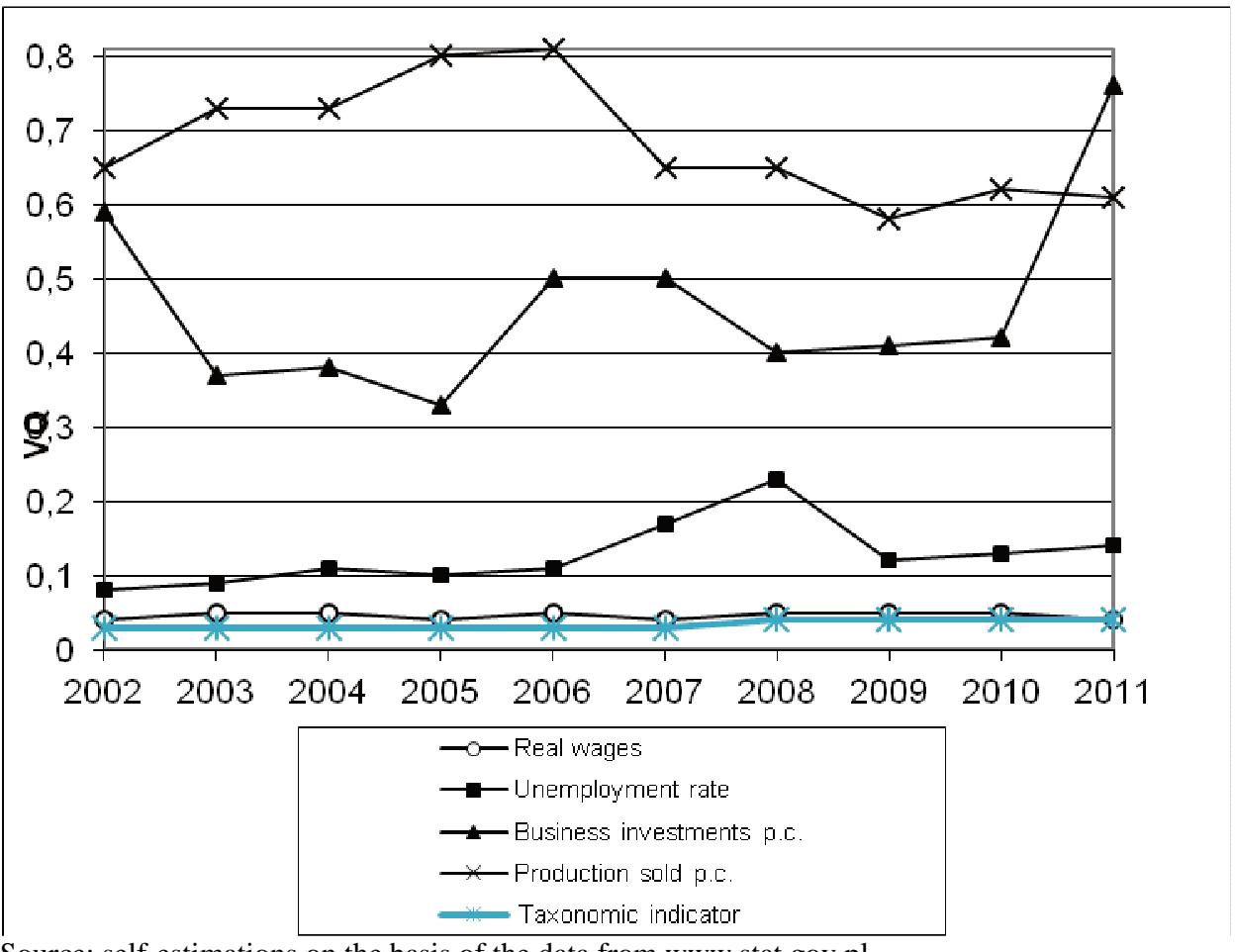

Source: self-estimations on the basis of the data from www.stat.gov.pl.

- While analysing the maximum-minimum wages ratio, it can be observed that in Podkarpackie Province it ranged from 1,3 (2002) to 1,38 (2009) as well as that it was one of the lowest levels of this coefficient amidst Polish provinces. It signifies that the average maximum gross wages were only from 30 to $38 \%$ higher than the average minimum wages.

- Among Polish provinces, this coefficient was characterised by the highest spatial heterogeneity in Dolnośląskie Province, where the maximum-minimum wages ratio was included in the range from $\sim 2$ to 2,5 throughout the entire period of the analysis.

- While considering spatial variation of registered unemployment rates, one can reach the conclusion that this variable was more spatially varied than average real gross wages. The maximum unemployment rates were recorded in the districts: Bieszczadzki (2002-2006 and 2008-2009), Leski (2007 and 2008) and Niżański 
(2011). The highest unemployment rate in Podkarpackie Province was registered in Bieszczadzki District in 2003, which amounted to almost $32 \%$ of the workforce9 .

- The lowest unemployment rates were registered in big urban agglomerations, i.e., in Rzeszów in 2002-2003 and 2008-2009 and in Krosno in 2004-2007 and 2010-2011. It should be emphasised that the maximum as well as the minimum values of this macroeconomic variable were characterised by a declining tendency in 2003-2007, and from 2008 the values of this variable started to increase, which was mainly caused by a global economic crisis which started in September 2008 in the USA, and the results of which are visible particularly in the analyses of Polish labour market, since, as opposed to commodity market, labour market in Poland transpired to be sensitive to the economic situation in the world.

- While analysing the obtained ratios of maximum-minimum unemployment rates, it can be concluded that the maximum values of this variable were from 2,77 (2002) to 4,85 (2008) times higher than the minimum registered unemployment rates in Podkarpackie Province. After 2008, the ratios of maximum-minimum unemployment rates started to decline and in 2011 reached the level of $~ 3,4$, which was mainly caused by the increase in unemployment rates, particularly in the districts where the level of this variable was the lowest, i.e., Rzeszów and Krosno.

- The highest level of gross business investments per capita was characteristic of Rszeszów District, where the investments amounted to from about PLN 3600 to PLN 5480 over a year. However, the highest level of this variable was registered in 2011 in Tarnobrzeski District, which was caused by huge investments in 2011 in Tarnobrzeg Special Economic Zone (inter alia, by Pilkington company which invested about PLN $220 \mathrm{mln}$ ). The lowest level of the business investments per capita was characteristic of Strzyżowski District, in which average business investments per capita ranged from PLN 190 to PLN 450.

- After analysing the variation of industrial production sold per capita, it transpires that the highest level of this variable was typical of Mielecki District, where industrial production sold per capita ranged between PLN 23850 (2002) and PLN 37000 (2011). Przemyski District had the lowest level of this variable; industrial production sold per capita did not exceed PLN 1000 over a year.

To compare economic development of the districts in Podkarpackie Province there were estimated taxonomic indicators of this development based on the distance of a particular district in Euclidean and rectilinear space from a cartain hypothetical model-

\footnotetext{
${ }^{9}$ The issue of spatial variation of district unemployment rates in Poland has been discused more extensively in: A. Adamczyk, T. Tokarski, R.W. Włodarczyk, Zróżnicowanie bezrobocia w województwach małopolskim $i$ podkarpackim, „Wiadomości Statystyczne” nr. 5/2008, A. Adamczyk, T. Tokarski, R.W. Włodarczyk, Przestrzenne zróżnicowanie płac w Polsce, „Gospodarka Narodowa” nr 9/2009, Ł. Jabłoński, T. Tokarski, Taksonomiczne wskaźniki przestrzennego zróżnicowania rozwoju powiatów, „Studia Prawno-Ekonomiczne” t. LXXXI/2010, T. Tokarski Przestrzenne zróżnicowanie bezrobocia rejestrowanego w Polsce w latach 1999-2006, „Gospodarka Narodowa” nr 7-8/2008, T. Tokarski, Regionalne zróżnicowanie bezrobocia, „Wiadomości Statystyczne” nr 5/2010 lub w pracy T. Misiak, A. Sulima, T.Tokarski, Czy wpolskich powiatach wystęuje efekt konwergencji realnej? [in:] W. Kwiatkowska, E. Kwiatkowski (ed.) Wzrost gospodarczy $i$ polityka makroekonomiczna, Wydawnictwo Uniwersytetu Łódzkiego, Łódź 2010.
} 
district. A model-district is such an object which would be characterised by the maximum value of every stimulant (from the ones included in taxonomical analysis) and the minimum value of every destimulant ${ }^{10}$. For this purpose, the following simple taxonomic procedure was applied $^{11}$ :

I. The set of stimulants and destimulants was determined. In this set, the stimulants of economic development are the previously analysed: industrial production sold per capita, business investments per capita, real gross wages, and the destimulant unemployment rate.

II. Destimulant was transformed into stimulant estimating its inverse.

III. The stimulants obtained in that way (industrial production sold per capita, business investments per capita, real gross wages, and the inverse of unemployment rate) were standardised using the equation:

$$
s_{i j t}=\frac{x_{i j t}}{\max _{i, t}\left(x_{i j t}\right)}
$$

where the indexes: $i$ refer to districts, $j$-simulants, $t$-years; $x_{i j t}$ is the value of $j$ simulant in $i$-district in $t$-year. Standardised simulants $s_{i j t}$, determined by equation (12) are characterised by the fact that the value of each one lies within the range $[0 ; 1]$. Value 1 denotes that in $\mathrm{i}$-district in t-year, $\mathrm{j}$-simulant obtained the maximum value among the districts over the entire analysed period. Whereas the value of this simulant equals $0, \mathrm{j}$-simulant in $\mathrm{i}$-district in $\mathrm{t}$-year obtained the minimum possible value.

IV. Subsequently, there were estimated the coefficients of economic development basing on the distance in Euclidean space:

$$
E D_{i t}=\sqrt{\frac{\sum_{j=1}^{6}\left(1-s_{i j t}\right)^{2}}{6}}
$$

and also in rectilinear space:

\footnotetext{
${ }^{10}$ In taxonomic analyses a stimulant is considered to be a variable the high value of which signifies a desired level of the examined phenomenon, whereas a destimulant is a feature the high value of which describes undesirable level of a given phenomenon. Thus, a stimulant of economic development of the provinces are, e.g., wages, and a destimulant - unemployment rate.

11 This type of the coefficients of taxonomic development of provinces and/or districts were used in the papers by: Edigarian A., P. Kościelniak, T. Tokarski, M. Trojak, Taksonomiczne wskaźniki rozwoju ekonomicznego powiatów [in:] D. Tomczak (ed.) Capability to social Progress In Poland's regions, Warsaw University Press, Warsaw 2011 or P. Dykas, P. Kościelniak, T. Tokarski [2013] Taksonomiczne wskaźniki rozwoju ekonomicznego województw i powiatów [in:] M. Trojak, T. Tokarski Statystyczna analiza zróżnicowania ekonomicznego i spotecznego Polski, Wydawnictwo Uniwersytetu Jagiellońskiego, Kraków 2013.
} 


$$
R D_{i t}=\frac{\sum_{j=1}^{6}\left|1-s_{i j t}\right|}{6}
$$

Taxonomic indicators (13-14) measure the distance included in the range $[0 ; 1]$ in Euclidean and rectilinear space of $i$-district in $t$-year from hypothetical modeldistrict. If the value of the indicator (13) or (14) equalled 0 , a given district would be characterised by a maximum value of every of the examined stimulants. The higher the value of this indicator, the lower the level of economic development of a given province.

V. Subsequently, the indicators (13-14) - in order to obtain one, synthetic indicator were averaged using geometric mean, and the data concerning the variation of the obtained indicator have been presented in table 2 .

Table 2. The variation of taxonomic indicator in Podkarpackie Province in 2002-2011

\begin{tabular}{|c|c|c|c|c|c|c|c|c|c|c|}
\hline & 2002 & 2003 & 2004 & 2005 & 2006 & 2007 & 2008 & 2009 & 2010 & 2011 \\
\hline \multicolumn{11}{|c|}{ Taxonomic indicator } \\
\hline \multirow{2}{*}{$\max$} & 0,89 & 0,89 & 0,89 & 0,89 & 0,89 & 0,89 & 0,88 & 0,88 & 0,87 & 0,87 \\
\hline & Niżański & Przemyski & Strzyżowski & Strzyżowski & Strzyżowski & Strzyżowski & Strzyżowski & Strzyżowski & Strzyżowski & Strzyżowski \\
\hline \multirow{2}{*}{$\min$} & 0,73 & 0,73 & 0,73 & 0,73 & 0,72 & 0,69 & 0,68 & 0,69 & 0,70 & 0,69 \\
\hline & Rzeszów & Rzeszów & Rzeszów & Rzeszów & Rzeszów & Rzeszów & Rzeszów & Rzeszów & Rzeszów & Rzeszów \\
\hline $\begin{array}{c}\max / \\
\min \end{array}$ & 1,23 & 1,21 & 1,22 & 1,23 & 1,24 & 1,28 & 1,29 & 1,27 & 1,25 & 1,27 \\
\hline \multicolumn{11}{|c|}{ The coefficient of variation } \\
\hline $\mathbf{V}_{\mathbf{Q}}$ & 0,03 & 0,03 & 0,03 & 0,03 & 0,03 & 0,03 & 0,04 & 0,04 & 0,04 & 0,04 \\
\hline $\mathbf{V}_{\mathrm{S}}$ & 0,05 & 0,05 & 0,05 & 0,05 & 0,06 & 0,06 & 0,07 & 0,06 & 0,06 & 0,06 \\
\hline $\mathbf{V}_{\mathrm{d}}$ & 0,04 & 0,04 & 0,04 & 0,04 & 0,04 & 0,05 & 0,05 & 0,04 & 0,04 & 0,05 \\
\hline
\end{tabular}

Source: self-estimations on the CSO's data from www.stat.gov.pl

It ensues from the data presented in table 2 that the most economically developed district in Podkarpackie Province was Rzeszów District, for which the calculated taxonomic indicator was the lowest and ranged between 0,68 (2008) and 0,73 (20022005). The least developed districts of Podkarpackie Province as regards the estimated taxonomic indicator were Niżański, Przemyski and Strzyżowski.

\section{INTRAREGIONAL $\beta$-CONVERGENCE OF THE SELECTED MACROECONOMIC VARIABLES IN PODKARPACKIE PROVINCE}

The main purpose of the present paper is the attempt to determine whether in Podkarpackie Province there is intraregional real $\beta$-convergence or divergence of the analysed variables, i.e.: registered unemployment rates, real gross wages, business investments per capita, industrial production sold per capita and also the estimated taxonomic indicator. Hence, in tables 3 and 4 there have been presented the results of the estimations of the equations (2-3) and (4-5) using generalized methods of moments (GMM). From these estimations the following conclusions of economic nature can be drawn: 
Table 3. The parameters of equations (2-3) estimated using GMM

\begin{tabular}{|c|c|c|c|c|c|}
\hline variable & $\begin{array}{l}\text { Real gross } \\
\text { wages }\end{array}$ & $\begin{array}{l}\text { Registered } \\
\text { unemployment } \\
\text { rate }\end{array}$ & $\begin{array}{l}\text { Industrial } \\
\text { production } \\
\text { sold } \\
\text { per capita }\end{array}$ & $\begin{array}{l}\text { Business } \\
\text { investments } \\
\text { per capita }\end{array}$ & $\begin{array}{c}\text { Taxonomic } \\
\text { indicator }\end{array}$ \\
\hline A constant & $\begin{array}{l}\mathbf{0 , 0 4 7 8 8 5} \\
(0,0497)\end{array}$ & $\begin{array}{l}\mathbf{0 , 0 1 8 4 6} \\
(0,0014)\end{array}$ & $\begin{array}{l}\mathbf{0 , 0 7 3 5 6} \\
(0,0002)\end{array}$ & $\begin{array}{l}\mathbf{0 , 2 7 7 5 9} \\
(0,0000)\end{array}$ & $\begin{array}{l}\mathbf{- 0 , 0 1 2 9 8} \\
(0,5293)\end{array}$ \\
\hline $\operatorname{Ln}\left(\mathbf{y}_{\mathrm{it}-1}\right)\left(\text { or } \mathbf{U}_{\mathrm{it}-1}\right)^{*}$ & $\begin{array}{l}\mathbf{- 0 , 0 0 0 0 1} \\
(0,2663)\end{array}$ & $\begin{array}{l}\mathbf{- 0 , 1 2 1 7} \\
(0,0000)\end{array}$ & $\begin{array}{c}\mathbf{- 0 , 0 0 1 8 7 8} \\
(0,0581)\end{array}$ & $\begin{array}{l}\mathbf{- 0 , 0 7 1 1 1} \\
(0,0031)\end{array}$ & $\begin{array}{l}\mathbf{0 , 0 0 9 7 5} \\
(0,6833)\end{array}$ \\
\hline $\begin{array}{l}\text { The rate of } \\
\text { convergence/divergence }\end{array}$ & - & $12,2 \%$ & $0,2 \%$ & $7,1 \%$ & - \\
\hline $\begin{array}{l}\text { Long-period theoretical } \\
\text { value of explanatory } \\
\text { variable }\end{array}$ & - & $15 \%$ & PLN 39300 & PLN 3900 & - \\
\hline $\begin{array}{l}\mathbf{R}^{2} \\
\text { Adjusted } \mathbf{R}^{2}\end{array}$ & $\begin{array}{l}0,00 \\
0,00\end{array}$ & $\begin{array}{l}0,083 \\
0,079\end{array}$ & $\begin{array}{l}0,01 \\
0,01\end{array}$ & $\begin{array}{l}0,037 \\
0,032\end{array}$ & $\begin{array}{c}0,002 \\
0,00\end{array}$ \\
\hline $\begin{array}{l}\text { J-Statistic } \\
\text { prob. (J-statistic) }\end{array}$ & $\begin{array}{c}3,8701 \\
(0,04915)\end{array}$ & $\begin{array}{c}2,3001 \\
(0,1294)\end{array}$ & $\begin{array}{c}0,039883 \\
(0,8417)\end{array}$ & $\begin{array}{l}2,03259 \\
(0,1540)\end{array}$ & $\begin{array}{c}0,0061 \\
(0,9371)\end{array}$ \\
\hline DW Statistic & 0,83 & 0,7 & 1,64 & 1,83 & 1,1 \\
\hline Instrumental variables ${ }^{* *}$ & 3 & 3 & 3 & 3 & 3 \\
\hline $\begin{array}{l}\text { The number of } \\
\text { observations }\end{array}$ & 200 & 200 & 200 & 200 & 200 \\
\hline
\end{tabular}

- in the case of the estimations for registered unemployment rates

** - The author, as instrumental variables used: a constant, two-year-lagged explanatory variable and one-year-lagged response variable.

Source: self-estimations.

Table 4. The parameters of equations (4-5) estimated using GMM with individual effects

\begin{tabular}{|c|c|c|c|c|c|}
\hline variable & $\begin{array}{l}\text { Real gross } \\
\text { wages }\end{array}$ & $\begin{array}{l}\text { Registered } \\
\text { unemployment } \\
\text { rate }\end{array}$ & $\begin{array}{l}\text { Industrial } \\
\text { production } \\
\text { sold } \\
\text { per capita }\end{array}$ & $\begin{array}{c}\text { Business } \\
\text { investments } \\
\text { per capita }\end{array}$ & $\begin{array}{c}\text { Taxonomic } \\
\text { indicator }\end{array}$ \\
\hline A constant & $\begin{array}{c}\mathbf{0 , 3 4 0 4 4 4} \\
(0,0006)\end{array}$ & $\begin{array}{l}\mathbf{0 , 0 5 2 4 6} \\
(0,0000)\end{array}$ & $\begin{array}{c}\mathbf{0 , 7 5 7 6} \\
(0,0021)\end{array}$ & $\begin{array}{c}\mathbf{1 , 9 1 9 2} \\
(0,0820)\end{array}$ & $\begin{array}{c}\mathbf{0 , 0 9 5 5} \\
(0,2466)\end{array}$ \\
\hline $\operatorname{Ln}\left(y_{i t-1}\right)\left(\text { or } U_{i t-1}\right)^{*}$ & $\begin{array}{l}\mathbf{- 0 , 0 0 0 1 1} \\
(0,0107)\end{array}$ & $\begin{array}{l}\mathbf{- 0 , 6 8 0 3} \\
(0,0000)\end{array}$ & $\begin{array}{c}\mathbf{- 0 , 0 3 7} \\
(0,0024)\end{array}$ & $\begin{array}{l}\mathbf{- 0 , 4 0 0 1} \\
(0,0094)\end{array}$ & $\begin{array}{l}\mathbf{- 0 , 1 4 3 3} \\
(0,2098)\end{array}$ \\
\hline $\begin{array}{l}\mathbf{R}^{2} \\
\text { Adjusted } \mathbf{R}^{2}\end{array}$ & $\begin{array}{l}0,05 \\
0,01\end{array}$ & $\begin{array}{l}0,15 \\
0,03\end{array}$ & $\begin{array}{l}0,25 \\
0,15\end{array}$ & $\begin{array}{c}0,21 \\
0,095\end{array}$ & $\begin{array}{c}0,095 \\
0,03\end{array}$ \\
\hline $\begin{array}{l}\text { J-Statistic } \\
\text { prob. (J-statistic) }\end{array}$ & 0,0000 & 0,0000 & 0,0000 & 0,0000 & $\begin{array}{c}4,3961 \\
(0,0361) \\
\end{array}$ \\
\hline DW Statistic & 0,70 & 0,61 & 1,68 & 1,87 & 1,1 \\
\hline $\begin{array}{l}\text { Instrumental } \\
\text { variables }\end{array}$ & 26 & 26 & 26 & 26 & 26 \\
\hline $\begin{array}{l}\text { Number of } \\
\text { observations }\end{array}$ & 200 & 200 & 200 & 200 & 200 \\
\hline
\end{tabular}

- in the case of the estimations for registered unemployment rates

** - The author, as instrumental variables used: a constant, two-year-lagged explanatory variable and one-year-lagged response variable, and also dummy variables that ensue from the procedure of fixed diversification.

Source: self-estimations. 
- In Podkarpackie Province, real gross wages were not influenced by the effects of $\beta$ convergence or real divergence. It ensues from the fact that, although lagged explanatory variable is negative - which can indicate $\beta$-convergence, the estimations of the parameters of equation (2) with GMM transpired to be statistically insignificant. Although the estimation of equation (4) proved statistical significance of $\beta$ parameter implying the effect of $\beta$-convergence, its power was very low, close to zero.

- While analysing the results of the estimated equation (3) of convergence/divergence of unemployment rates, it transpires that this variable undergoes the processes of $\beta$-convergence inside Podkarpackie Province. The rate of real convergence of registered unemployment rates in Podkarpacie was estimated at the level of $12,2 \%$, which signifies that if in the previous year the unemployment rate increased about 1 percentage point, it would cause increase in unemployment rate of $12,2 \%$ lower (if this rate was growing) or larger decrease in in this rate (if the unemployment rate was declining). In the estimations of equation (5) with fixed effects, the convergence rate was decidedly higher and amounted to about $68 \%$.

- On the basis of the estimated parameters of the equation of 'pure' convergence/divergence there can be determined theoretical value of long-period registered unemployment rate for Podkarpackie Province, which amounted to $15 \%{ }^{12}$. This determined theoretical long-period unemployment rate in Podkarpacie reached a high level, which appears to have resulted from the global crisis in 2008, which caused a significant growth in unemployment rates at the level of districts in Podkarpackie Province. The determined theoretical value of long-period natural unemployment rate at the level of districts for the entire Polish economy was considerably lower than in Podkarpackie Province and amounted to approx. 6\% of the entire workforce, which corresponds with the theoretical estimations of natural unemployment rate for Polish economy. However, if the long-period unemployment rate is estimated from equation (5), the value of this rate is about twice lower and amounts to 7,7\%, except that, due to the effect of fixed diversification in equation (5), this rate will concern Rzeszów District. Taking into consideration the values of real registered unemployment rates for Rzeszów District, it appears that the obtained level of 7,7\% is overestimated of at least twothree percentage points.

- Corrected coefficient of determination (corr. $\mathrm{R}^{2}$ ), in the case of registered unemployment rate, amounted to approx. $8 \%$ in the estimation of equation (3) and about $3 \%$ in the estimation of equation (5), which implies that lagged unemployment rate explained the variability of unemployment rates in this period ${ }^{13}$ in about $8 \%$ (approx. 3\% for equation (5)).

\footnotetext{
${ }^{12}$ It appears justified that a long-period theoretical value of unemployment rate can be equated with a long-period natural unemployment rate. In long period, unemployment rate, according to, e.g., the concept of long-period Philips curve, should approach the level of natural unemployment rate.

${ }^{13}$ It is worth emphasising that the aim of this type of convergence equations is not the possibly highest determination coefficient but the observation whether lagged variable statistically significantly influences the growth rate of this variable.
} 
- Gross industrial production sold per capita was influenced by $\beta$-convergence, which is indicated by statistically significant parameters of the estimated equations (2) and (4), however, the convergence rate was higher for the estimation of equation (4). The estimated long-period value of the investments amounted to approx. PLN 39300.

- Business investments per capita, likewise gross industrial production sold, were influenced by the process of real $\beta$-convergence, the power of which was estimated at about $7 \%$ (equation (2)) and at as much as $40 \%$ for equation (4). It signifies that this variable was growing quicker in the districts in which it was the lowest. Basing on the estimated parameters of equation (2), there was also estimated long-period theoretical value of business investment outlays, which in Podkarpackie Province amounted to approx. PLN 3900 per year per capita.

- It ensues from the estimations of long-period theoretical values of gross industrial production sold and business investments that the rate of business investments from industrial production sold amounts to about $10 \%$.

- The estimated parameters of convergence equations for taxonomic indicator transpired statistically insignificant in the equation of 'pure' convergence as well as in the equation with individual fixed effects.

\section{CONCLUSION}

The considerations conducted in the paper can be concluded as follows:

I. The highest values of business investments per capita and also real gross wages in 2002-2011 were registered in Rzeszów - the capital city of the province. In the same province there was recorded one of the lowest registered unemployment rates and one of the higher levels of industrial production sold per capita. Such situation appears to be justified by the fact that the capital cities of provinces frequently become actual pole of development of a given region, contributing to a considerable extent to quicker development of the entire region, catching up with richer and more developed regions.

II. The highest unemployment rates were registered in the south of the region (Bieszczadzki, Leski and Brzozowski districts) and also in Niżański District, which, to a large extent ensues from geographical conditions, since it is hard to imagine a quick industrial development and the creation of new factories which generates new workplaces in such districts as Bieszczadzki or Leski.

III. The lowest unemployment rates were registered in big cities of this region, i.e., Rzeszów and Krosno. Interestingly, in such district cities as Tarobrzeg and Przemyśl unemployment rates were equal or even higher than the average registered unemployment rate of the entire Podkarpackie Province.

IV. Among the variables analysed in the paper, real gross wages were characterised by the lowest intraregional spatial variation. Whereas most spatially varied variables were: industrial production sold per capita and business investments per capita. Moreover, basing on the analysis of the changes in the values of the coefficients of variation neither the process of real $\sigma$-convergence nor $\sigma$ divergence can be observed.

V. Statistical analyses of real $\beta$-convergence indicate that in the period of the analysis this process was observed only in the case of the registered 
unemployment rates, industrial production sold per capita and business investments per capita. However, owing to the procedure of estimation, the speeds of convergence of particular macroeconomic variables varied. The highest speed of convergence in Podkarpackie Province was observed in the case of registered unemployment rates.

\section{LITERATURE:}

[1] Adamczyk A., T. Tokarski, R.W. Włodarczyk [2008] Zróżnicowanie bezrobocia $w$ województwach małopolskim i podkarpackim, „Wiadomości Statystyczne” nr 5.

[2] Adamczyk A., T. Tokarski, R.W. Włodarczyk [2009] Przestrzenne zróżnicowanie płac w Polsce, „Gospodarka Narodowa” nr 9.

[3] Di Liberto A., Mura R., Pigliaru F. [2004] How To Measure The Unobservable: A Panel Technique For Analysis of TFP Convergence, Centro Richerche Economiche Nord Sud working paper 2004/05, Universita do Cagliari.

[4] Edigarian A., P. Kościelniak, T. Tokarski, M. Trojak [2011] Taksonomiczne wskaźniki rozwoju ekonomicznego powiatów [in:] D. Tomczak (ed.) [2011].

[5] Gramic B. [2006] Convergence in per-capita GDP across European regions, "Economic and Business Review", vol. 8, no. 2, pp. 185-208.

[6] Islam N. [2003] What Have We Learnt From the Convergence Debate, „Journal of Economic Surveys", vol. 17(3).

[7] Jabłoński Ł., Misiak T., [2013] Realna konwergencja między regionami Unii Europejskiej $w$ latach 1995-2008, Studia Prawno-Ekonomiczne t. LXXXVIII, Łódzkie towarzystwo Naukowe, Łódź.

[8] Jabłoński Ł., Tokarski T., [2010] Taksonomiczne wskaźniki przestrzennego zróżnicowania rozwoju powiatów, opracowanie przesłane do redakcji „Studiów Prawno-Ekonomicznych".

[9] Jóźwiak J., Podgórski J. [2000] Statystyka od podstaw, PWE, Warszawa.

[10] Kwiatkowska W., E. Kwiatkowski (ed.) [2010] Wzrost gospodarczy i polityka makroekonomiczna, Wydawnictwo Uniwersytetu Łódzkiego, Łódź.

[11] Meliciani V., Peracchi F. [2006] Convergence in per capita GDP across European regions: a reappraisal, "Empirical Economics", vol. 31.

[12] Malaga K. [2004] Konwergencja gospodarcza w krajach OECD w świetle zagregowanych modeli wzrostu, Prace habilitacyjne, $\mathrm{nr}$ 10, Wydawnictwo Akademii Ekonomicznej w Poznaniu, Poznań.

[13] Misiak T. [2008] Zależność między inwestycjami i wydatkami rzadowymi a wzrostem gospodarczym $w$ krajach Unii Europejskiej, „Wiadomości Statystyczne" nr 7.

[14] Misiak T., A. Sulima, T. Tokarski [2010] Czy w polskich powiatach występuje efekt konwergencji realnej? w W. Kwiatkowska, E. Kwiatkowski [2010].

[15] Próchniak M., Rapacki R. [2009] Konwergencja typu beta $(\beta)$ i sigma $(\sigma) w$ krajach transformacji w latach 1990-2005, w: pod red.: R. Rapacki, Wzrost gospodarczy w krajach transformacji. Konwergencja czy dywergencja?, PWE, Warszawa.

[16] Sassi M. [2010] OLS and GWR approaches to agricultural convergence in the EU-15, "International Advances in Economic Research", vol. 16, no.1. 
[17] Sassi M. [2011] Convergence across the EU regions: Economic composition and structural transformation, "International Advances in Economic Research", vol. 17.

[18] Tokarski T. [2005] Statystyczna analiza regionalnego zróżnicowania wydajności, zatrudnienia i bezrobocia w Polsce, Wydawnictwo PTE, Warszawa.

[19] Tokarski T. [2008] Przestrzenne zróżnicowanie bezrobocia rejestrowanego $w$ Polsce w latach 1999-2006, „Gospodarka Narodowa” nr 7-8.

[20] Tokarski T. [2010] Regionalne zróżnicowanie bezrobocia, „Wiadomości Statystyczne" nr 5.

[21] T.Tokarski, G. Wilk-Jakubowski, T. Misiak (red.) [2012] Makroekonomiczne zróżnicowanie rozwoju województwa podkarpackiego, Wydawnictwo Stowarzyszenia Współpracy Polska-Wschód, Kielce.

[22] Tomczak D. (ed.) [2011] Capability to social Progress In Poland's regions, Warsaw University Press, Warsaw.

\section{KONWERGENCJA CZY DYWERGENCJA PODSTAWOWYCH ZMIENNYCH MAKROEKONOMICZNYCH NA POZIOMIE POWIATÓW W WOJEWÓDZTWIE PODKARPACKIM}

W niniejszym opracowaniu przedstawiono wyniki analiz statystycznych procesów $\sigma$ oraz $\beta$ konwergencji realnej wybranych zmiennych makroekonomicznych na poziomie powiatów w województwie podkarpackim. W pracy wykorzystano dane dotyczące stóp bezrobocia , płac realnych brutto, inwestycji przedsiębiorstw na mieszkańca oraz produkcji sprzedanej przemysłu brutto na mieszkańca w latach 2002-2011, uzyskane z Banku Danych Lokalnych Głównego Urzędu Statystycznego. Ponadto na podstawie tych danych obliczono taksonomiczny wskaźnik rozwoju województwa podkarpackiego, który również poddano analizie statystycznej. Głównym celem opracowania była zatem weryfikacja hipotezy o wystepowaniu konwergencji analizowanych zmiennych oraz obliczonego taksonomicznego wskaźnika rozwoju na poziomie powiatów województwa podkarpackiego. Analizy $\sigma$ konwergencji przeprowadzono w oparciu o wskaźniki przestrzennego zróżnicowania wyżej wymienionych zmiennych, tj.: maksimum, minimum, relacja maksimum/minimum, współczynniki zmienności oparte na odchyleniach kwartylowym $\left(\mathrm{V}_{\mathrm{Q}}\right)$, standardowym $\left(\mathrm{V}_{\mathrm{S}}\right)$ oraz przeciętnym $(\mathrm{Vd})$. Wartości obliczonych współczynników zmienności pozwoliły zaobserwować przestrzenną heterogeniczność analizowanych zmiennych oraz taksonomicznego wskaźnika rozwoju, zaś ich zmiany w czasie zidentyfikować zjawisko $\sigma$ konwergencji bądź $\sigma$-dywergencji. Natomiast analizy $\beta$ konwergencji realnej polegały na estymacji parametrów równania „czystej konwergencji” typu Barro. Ponadto w celu uwzględnienia przestrzennej heterogeniczności analizowanych zmiennych równania konwergencji realnej rozszerzono wprowadzając efekty indywidualne typu fixed (fixed effect). Zaproponowane w artykule równania poddano estymacji panelowej wykorzystując metodę zmiennych instrumentalnych najbardziej odpowiednią do tego typu równań czyli uogólniona metode momentów (UMM).

Słowa kluczowe: konwergencja, dywergencja, rynek pracy, taksonomiczny wskaźnik rozwoju, stopa bezrobocia lokalnego, płace realne brutto, produkcja sprzedana przemysłu per capita, uogólniona metoda momentów (UMM).

DOI:10.7862/rz.2014.hss.61

Przesłano do redakcji: lipiec 2014

Przyjęto do druku: grudzień 2015 